Article

\title{
Increased As Adsorption on Maghemite-Containing Red Mud Prepared by the Alkali Fusion-Leaching Method
}

\author{
Andrei A. Shoppert *(D), Irina V. Loginova, Denis A. Rogozhnikov, Kirill A. Karimov and \\ Leonid I. Chaikin \\ Department of Non-ferrous Metals Metallurgy, Ural Federal University named after the first President of Russia \\ B.N. Yeltsin, Yekaterinburg 620002, Russia; loginova_irina@mail.ru (I.V.L.); darogozhnikov@yandex.ru (D.A.R.); \\ kirill_karimov07@mail.ru (K.A.K.); leonidii91073@gmail.com (L.I.C.) \\ * Correspondence: andreyshop@list.ru; Tel.: +7-922-024-3963
}

Received: 20 December 2018; Accepted: 17 January 2019; Published: 20 January 2019

check for updates

\begin{abstract}
This study investigates the use of red muds as adsorbents for As (V) removal. Red mud is a waste that contains a large amount of iron oxides and hydroxides, which are excellent adsorbents of arsenic, especially those possessing magnetic properties and a large specific surface area. The purpose of the experiments was to study the possibility of obtaining an effective adsorbent by the direct extraction of alumina from bauxite using the caustic alkali fusion method and to compare the arsenic removal effectiveness and other properties of these red muds with industrial samples. Red muds were described using methods such as X-ray diffraction spectrometry (XRD), X-ray fluorescence spectrometry (XRF), SEM, vibrating sample magnetometry (VSM), and the Brunauer-Emmett-Teller (BET) method. The main iron-containing phase of the red muds obtained by fusing bauxite with caustic alkali is maghemite, which has a large specific surface area. The specific surface area of the obtained samples varied in the range of $6.1-54.9 \mathrm{~m}^{2} / \mathrm{g}$. Arsenic adsorption experiments were carried out using five different types of red muds: industrial Bayer, industrial sintering, and red mud obtained through bauxite alkali fusion at 300,500 , and $700{ }^{\circ} \mathrm{C}$. The red muds obtained by fusing bauxite with caustic alkali at 300 and $500{ }^{\circ} \mathrm{C}$ had the highest effectiveness removing arsenic; their $\mathrm{As}(\mathrm{V})$ uptake capacity was over $30 \mathrm{mg} / \mathrm{g}$.
\end{abstract}

Keywords: arsenate; adsorption; red mud; alkali fusion-leaching; bauxite; maghemite; magnetic nanoparticles

\section{Introduction}

Red mud is a technogenic waste produced by the alkaline processing of bauxite into alumina using Bayer or sintering methods [1-4]. Each year, over 100 million tons of red mud are produced; the mud yield depends on the feedstock and the processing method $[5,6]$. For instance, low-quality feedstock yields more red mud than it produces alumina. Most plants dispose of red mud in bauxite residue disposal areas as pulp, with the $\mathrm{pH}$ of the pulp reaching 13 units due to the caustic alkali used for processing.

Red mud mainly consists of iron, aluminum, and titanium oxides, as well as various silicates, which are initially present in bauxites and are formed during processing. With its small particles, special chemical composition, and high $\mathrm{pH}$, red mud causes great damage to the environment at the disposal sites. This was very clearly demonstrated by the environmental disasters that occurred in Eastern Europe over the past decades [7,8], which even resulted in human deaths, not to mention environmental damage. This makes red mud processing a challenge for the aluminum industry, which has yet to find a way to avoid its accumulation. 
One of the possible ways to do this is through revegetation, which mainly involves attempts to convert disposal areas into land suitable for crop growth [9-12]. The industry has also developed a large number of methods to convert red mud into valuable products. The most ambitious are the production of construction materials and steels [13-16], since the requirements for raw materials are very high in these industries. The use of red mud in the production of ceramics, rare earth metals [17,18], etc. have also been proposed, as described in detail in a number of reviews $[13,15,19,20]$. One of the useful properties of red mud is the ability to adsorb harmful impurities from gases and liquids, including sulfur oxides [21], heavy non-ferrous metals [22-24] and ions of weak acids, the most harmful of which are arsenic and antimony compounds [25].

Arsenic is one of the most dangerous elements found in a large number of natural compounds [26,27]. In many countries, most notably Asia, its content in groundwater exceeds threshold values [28-30]. Mines and sulfide mineralization sites are the main sources of arsenic, with large amounts released by enterprises that store waste in dams without proper pre-treatment. In the Ural region of Russia, the main source of arsenic is the copper industry, which processes arsenic-containing concentrates [31]. Their pyro- and hydrometallurgical processes generate effluent containing up to $1 \mathrm{~g} / \mathrm{L}$ of arsenic, which needs proper treatment before rejection [32].

Arsenic causes a broad set of dangerous diseases such as diabetes, digestive, cardiovascular, and neurological conditions, and increases the risk of cancer [33,34]. Many countries have already adopted rules limiting the arsenic content in drinking water to $0.01 \mathrm{mg} / \mathrm{L}$, as recommended by the World Health Organization (WHO) and the United States Environmental Protection Agency (USEPA) [35,36].

A large number of arsenic water treatment methods have been proposed such as oxidation and precipitation [37], coagulation [38], co-precipitation [39], the use of membranes and reverse osmosis [40], electrolysis [41], and ion exchange [42]. However, these methods are rather complicated, expensive, or generate waste, and are less effective at very low concentrations of arsenic. Adsorption thus remains the most common and economical method [43].

A large number of studies have shown that arsenic can be efficiently extracted from water by iron oxides and hydroxides with a large specific surface area, as described in detail in Reference [44]. In turn, red mud $\mathrm{Fe}_{2} \mathrm{O}_{3}$ content is often more than $50 \%$, and a large number of studies have been conducted to investigate its use as a sorbent in water treatment for arsenic and other harmful impurities, as shown in Reference [45]. However, red mud in its raw form has a significantly lower arsenic capacity compared to synthesized iron oxide adsorbents; a number of authors have therefore proposed methods of red mud pre-activation by carbonization [46], treatment with acids [47], various salts [48], seawater [49], and heat [50], as well as a combination of several methods [51] and mixing red mud with organic and inorganic materials [52-54].

These methods can significantly increase the capacity of red mud, to make it just as effective an adsorbent as a synthesized one, but they involve added operations associated with the neutralization of caustic alkali and roasting. In addition, the resulting product is difficult to filter in batch experiments, or it must be pelletized. A number of authors have shown that the problem with filtration can be solved by obtaining new types of iron oxide adsorbents with magnetic properties-magnetite and maghemite [55-59].

Akin et al. [60] proposed the obtention of such compounds from red mud by dissolving it with acid, followed by precipitation of the necessary oxides, which is rather costly. Developing new methods for obtaining red mud with magnetic properties and a high specific surface area would thus significantly reduce the cost of wastewater and drinking water treatment for arsenic and other harmful impurities.

To solve these problems, this paper proposes a red mud production method based on fusing bauxites with caustic alkali, as shown in our previous works and the works of other authors [61-65]. The most important advantages of the method as compared to the Bayer method are the ability to decompose diaspore-boehmite bauxites without the use of high-temperature autoclave leaching and a significantly smaller yield of red mud; at the same time, iron compounds turn into ferrites, which 
are then leached under certain conditions to produce iron oxides and hydroxides with a high specific surface area and magnetic properties $[64,65]$. However, the use of red mud obtained by this method as an adsorbent for arsenic removal without additional treatment has not yet been studied.

The magnetic properties and the specific surface area of alkali fusion red mud depend strongly on the fusion temperature. Therefore, this work studied the effect of the temperature of bauxite fusion with caustic alkali on the properties of the resulting red mud and on the efficiency of arsenic removal from solutions by adsorption as compared with industrial red muds.

\section{Materials and Methods}

\subsection{Reagents}

The chemicals used in this study were reagent grade; the water was distilled in a GFL 2004 distiller. $\mathrm{NaOH}$ was supplied by JSC Bashkir Soda Company (Sterlitamak, Russia). The two types of industrial red mud (Bayer's and sintering) were obtained from an alumina refinery in Kamensk-Uralsky (Sverdlovsk Region, Russia) that processes bauxite from the Middle-Timan deposit in Russia to produce alumina by the combined Bayer-sintering method. The third red mud type was obtained by fusing the same bauxite with caustic alkali at different temperatures. The original solution with a concentration of $1 \mathrm{~g} / \mathrm{L} \mathrm{As}(\mathrm{V})$ was obtained from the Ural Mining and Metallurgical Company (Verkhnyaya Pyshma, Russia).

\subsection{Adsorbent Preparation}

The synthesized red mud was obtained from bauxite by fusing it with caustic alkali. A 20-g bauxite sample was crushed to $80 \%$ of particles less than $74 \mu \mathrm{m}$ and thoroughly mixed with $20 \mathrm{~g}$ caustic alkali; then $10 \mathrm{~mL}$ water was added to the mixture. The produced pulp was placed in a 100-mL ceramic crucible and mixed well into a homogeneous mixture. The crucible was then placed in a muffle furnace MIMP-10P (LLC MIUS, Moscow, Russia), heated up from room temperature to the desired temperatures ( of $300{ }^{\circ} \mathrm{C}, 500{ }^{\circ} \mathrm{C}$ or $700{ }^{\circ} \mathrm{C}$ ), and then left in the furnace for $1.5 \mathrm{~h}$. The obtained sinter was studied for phase composition and subsequent leaching.

The sinter was crushed by hand using an agate pestle to pass $100 \%$ of the particles through a $150-\mu \mathrm{m}$ sieve and was then leached. For that purpose, the crushed sinter was placed in a 200-mL flask containing $100 \mathrm{~mL}$ water and leached for $30 \mathrm{~min}$ at $80^{\circ} \mathrm{C}$. The resulting pulp was filtered, and the solid residue (red mud) was repeatedly washed with hot water to reach a neutral $\mathrm{pH}$. The washed red mud was dried at $80^{\circ} \mathrm{C}$ overnight to prevent phase transformations of iron oxides and hydroxides. The red mud thus obtained was analyzed by various physicochemical methods and tested for effectiveness as an adsorbent of arsenic.

\subsection{Adsorbent Characterization}

The study of the phase composition of bauxite, sinter, and red mud was performed through powder X-ray diffraction spectrometry (XRD) with a Rigaku D/MAX-2200 diffractometer using a $\mathrm{Cu}-\mathrm{K} \alpha$ radiator $(\lambda=1.541841 \AA$ ) and a PDF-2 database (International Center for Diffraction Data). The chemical composition of bauxite and red mud was determined using powder $X$-ray fluorescence spectrometry (XRF) with an XRF-1800 detector. Scanning electron microscopy (SEM) images were taken to determine the morphology of red muds (JEOL JSM-6390, Tokyo, Japan). Vibrating sample magnetometer (VSM) was used to determine the magnetic properties of red muds (LakeShore 7407). A gas adsorption analyzer with the Brunauer-Emmett-Teller (BET) method (Gemini VII 2390 Surface Area Analyzer) was used for surface area and micropore volume determination. Zero charge point was determined by Zetasizer Nano ZS (Malvern Instruments Inc., Worcestershire, UK). The Loss on Ignition (LOI) was determined by a Diamond TG/DTA (PerkinElmer, Waltham, MA, USA), by heating a sample from 50 to $1000{ }^{\circ} \mathrm{C}$ at a rate of 20 degrees per minute. 


\subsection{Adsorption Experiments}

Arsenic adsorption experiments were performed by mixing a certain amount of red mud $(10 \mathrm{~g} / \mathrm{L})$ with an As (V) solution of a known concentration in a plastic Erlenmeyer flask. The Erlenmeyer flasks were agitated at $100 \mathrm{rpm}$ with an ECROS laboratory shaker (LLC ECROSKHIM, Russia) at a room temperature of $25 \pm 2{ }^{\circ} \mathrm{C}$ until pseudo-equilibrium was reached [66]. Arsenic adsorption by different types of red mud was tested with an initial concentration of As (V) of $156 \mathrm{mg} / \mathrm{L}$ for $48 \mathrm{~h}$. Adsorption kinetics was tested at different time intervals at an initial $\mathrm{pH}$ of 2.3 and an initial concentration of As (V) $117 \mathrm{mg} / \mathrm{L}$. Based on the adsorption kinetics tests, $24 \mathrm{~h}$ were decided upon to ensure that pseudo-equilibrium was achieved. The effect of $\mathrm{pH}$ was tested at an initial concentration of $117 \mathrm{mg} / \mathrm{L}$ As $(\mathrm{V})$ at various initial $\mathrm{pH}$ values of the solution, which was controlled using $0.1 \mathrm{M}$ solutions of $\mathrm{NaOH}$ and $\mathrm{H}_{2} \mathrm{SO}_{4}$. Adsorption isotherms were obtained by varying the initial concentration of $\mathrm{As}(\mathrm{V})$ in the solution in the range of $39-500 \mathrm{mg} / \mathrm{L}$.

Upon reaching the adsorption equilibrium, the red mud was separated by centrifuge; the solution was then collected to determine the final As $(\mathrm{V})$ content using inductively coupled plasma mass spectrometry (ICP-MS, NexION 300S, PerkinElmer). All the tests were performed twice; the mean values are presented here.

The sorbent capacity was determined by the mass balance formula, expressed as Equation (1):

$$
\mathrm{q}_{\mathrm{e}}=\left(\mathrm{C}_{\mathrm{i}}-\mathrm{C}_{\mathrm{f}}\right) \times \mathrm{V} / \mathrm{m},
$$

where $\mathrm{q}_{\mathrm{e}}$ is the sorbent capacity in $\mathrm{mg} / \mathrm{g}, \mathrm{C}_{\mathrm{i}}$ and $\mathrm{C}_{\mathrm{f}}$ are the initial and final concentrations of arsenic in $\mathrm{mg} / \mathrm{L}, \mathrm{V}$ is the solution volume in $\mathrm{dm}^{3}$, and $\mathrm{m}$ is the sorbent mass in $\mathrm{g}$.

All the adsorption isotherms data were compared graphically against Langmuir (Equation (2)) and Freundlich equations (Equation (3)):

$$
\begin{gathered}
\mathrm{q}_{\mathrm{e}}=\left(\mathrm{K}_{\mathrm{L}} \times \mathrm{q}_{\max } \times \mathrm{C}_{\mathrm{e}}\right) /\left(1+\mathrm{K}_{\mathrm{L}} \times \mathrm{C}_{\mathrm{e}}\right), \\
\mathrm{q}_{\mathrm{e}}=\mathrm{K}_{\mathrm{F}} \times \mathrm{C}_{\mathrm{e}}^{1 / \mathrm{n},}
\end{gathered}
$$

where $\mathrm{q}_{\mathrm{e}}$ is the sorbent capacity in $\mathrm{mg} / \mathrm{g}, \mathrm{K}_{\mathrm{L}}$ is the Langmuir constant (the value of the virtual strength of the bond between the substance and the sorbent) in $\mathrm{L} / \mathrm{mg}, \mathrm{q}_{\max }$ is the maximum attainable sorbent capacity in $\mathrm{mg} / \mathrm{g}, \mathrm{C}_{\mathrm{e}}$ is the equilibrium concentration in $\mathrm{mg} / \mathrm{L}, \mathrm{K}_{\mathrm{F}}$ is the Freundlich constant $(\mathrm{mg} / \mathrm{g}$ ) $(\mathrm{L} / \mathrm{mg})^{1 / \mathrm{n}}$, and $1 / \mathrm{n}$ is a dimensionless parameter of Freundlich adsorption intensity.

\section{Results and Discussion}

\subsection{Sorbent Preparation}

The third type of red mud was obtained using the same Middle-Timan bauxite as that used in the Bayer process at the Ural Aluminum Plant. The chemical composition of the used bauxite is presented in Table 1. Figure 1 shows the XRD pattern of the bauxite. As can be seen from the data in Table 1 and Figure 1, this bauxite mainly consisted of boehmite and hematite, with small amounts of rutile, diaspore, calcite, and chamosite. The presence of ferrous iron was associated with the chamosite phase. This bauxite was characterized by a high iron content, which makes it a good object to study the possibility of obtaining an iron oxide-based adsorbent from red mud.

Table 1. The chemical composition of Middle-Timan bauxite, wt. \%.

\begin{tabular}{cccccccccc}
\hline $\mathrm{Al}_{2} \mathrm{O}_{3}$ & $\mathrm{Fe}_{2} \mathrm{O}_{3}$ & $\mathrm{FeO}$ & $\mathrm{SiO}_{2}$ & $\mathrm{TiO}_{2}$ & $\mathrm{CaO}$ & $\mathrm{CO}_{2}$ & $\mathbf{M g O}$ & LOI & $\mu \mathrm{Si}$ \\
\hline 51.00 & 25.36 & 2.38 & 4.44 & 2.84 & 0.62 & 0.60 & 0.33 & 11.15 & 11.49 \\
\hline \multicolumn{7}{c}{ Note: $\mu \mathrm{Si}$, a silica ratio equal to the mass ratio of alumina to silica in bauxite; LOI, loss on ignition. }
\end{tabular}


The fusion of bauxite with caustic alkali causes various chemical interactions, and the main interactions are described by Equations (4)-(6):

$$
\begin{gathered}
\mathrm{AlOOH}+\mathrm{NaOH}=\mathrm{NaAlO}_{2}+\mathrm{H}_{2} \mathrm{O}, \\
\mathrm{Fe}_{2} \mathrm{O}_{3}+2 \mathrm{NaOH}=2 \mathrm{NaFeO}_{2}+\mathrm{H}_{2} \mathrm{O}, \\
\mathrm{SiO}_{2}+2 \mathrm{NaOH}=\mathrm{Na}_{2} \mathrm{SiO}_{3}+\mathrm{H}_{2} \mathrm{O},
\end{gathered}
$$

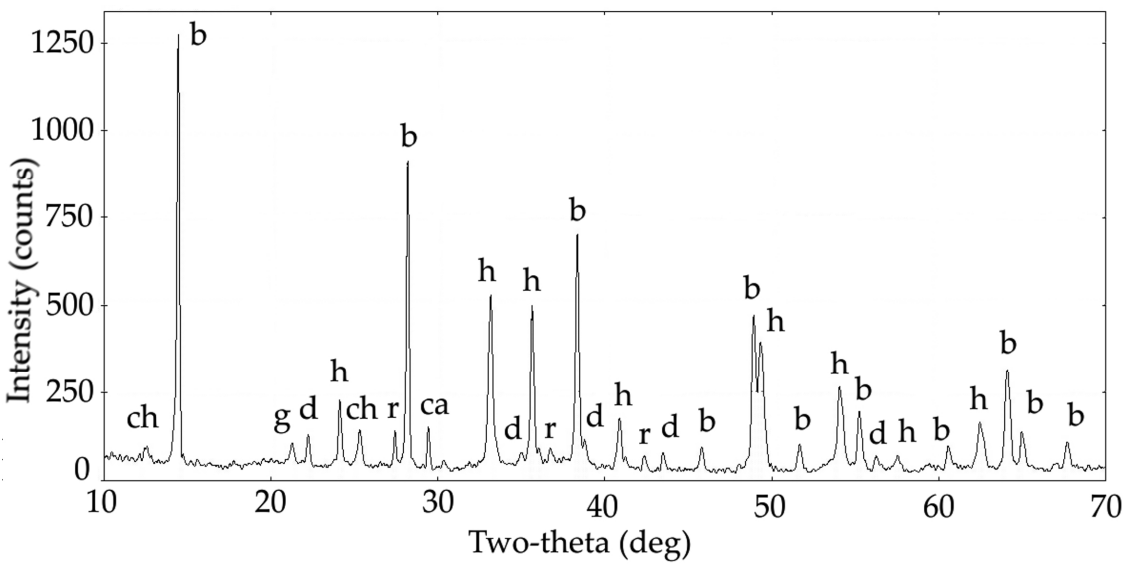

Figure 1. The X-ray diffraction (XRD) pattern of the Middle-Timan bauxite, where: $b$, boehmite; $h$, hematite; g, gibbsite; $d$, diaspore; ca, calcite; r, rutile; and ch, chamosite.

Figure 2 shows the XRD pattern of the sinters obtained by fusing bauxite with caustic alkali at different temperatures. As shown, sodium aluminate and sodium ferrite are indeed the main phases. Since caustic alkali was taken with some excess (the molar ratio $\mathrm{Na} 2 \mathrm{O} /\left(\mathrm{Al}_{2} \mathrm{O}_{3}+\mathrm{Fe}_{2} \mathrm{O}_{3}\right)=1.85$ ), peaks corresponding to sodium hydroxide can be seen in the XRD pattern. The amounts of sodium silicate or other silicon compounds are insignificant, so their peaks are practically invisible.

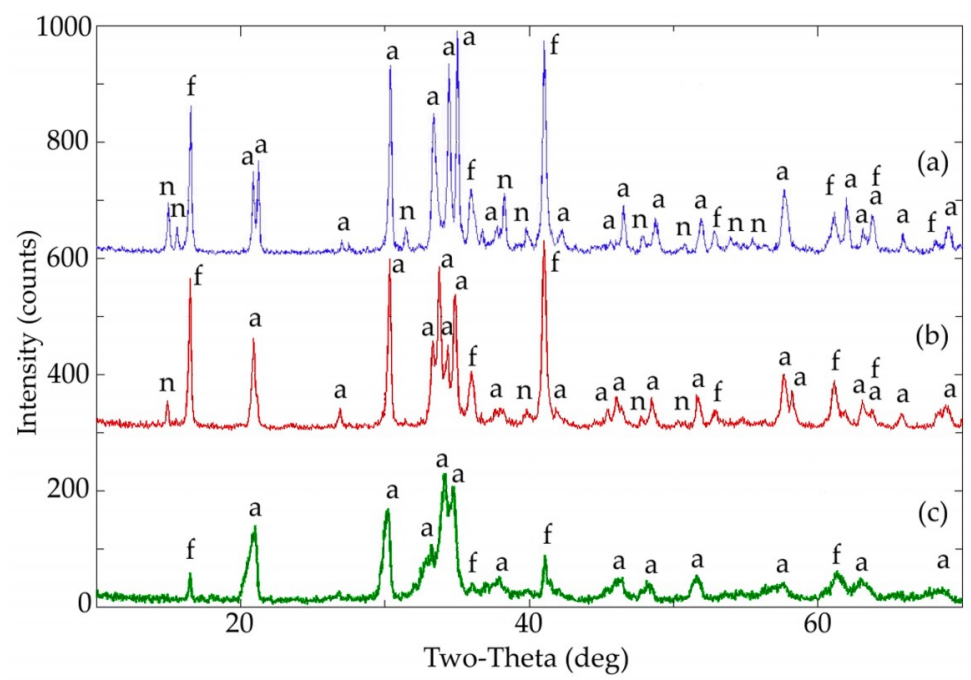

Figure 2. XRD pattern of sinters: (a) sinter obtained by fusion at $300{ }^{\circ} \mathrm{C}$; (b) sinter obtained by fusion at $500{ }^{\circ} \mathrm{C}$; (c) sinter obtained by fusion at $700{ }^{\circ} \mathrm{C}$. The letters stand for: a, sodium aluminate; $\mathrm{f}$, sodium ferrite; $n$, sodium hydroxide.

As the temperature rises, one can see changes in the characteristic peaks of aluminate, as well as a decrease in the intensity of the ferrite and sodium hydroxide peaks. Thus, the sodium hydroxide phase is observed at $300{ }^{\circ} \mathrm{C}$ and $500{ }^{\circ} \mathrm{C}$ and disappears at $700{ }^{\circ} \mathrm{C}$. The intensity of the peaks corresponding to 
sodium ferrite is significantly reduced at $700{ }^{\circ} \mathrm{C}$, which may be due to structural changes. With an increase in temperature, peaks corresponding to sodium aluminate also change to peaks of sodium aluminosilicate $\mathrm{Na}_{1.95} \mathrm{Al}_{1.95} \mathrm{Si}_{0.05} \mathrm{O}_{4}$, which indicates the beginning of the reaction of silicon compounds with caustic alkali.

These changes affect the properties of the resulting red mud and the alumina extraction degree in subsequent leaching, as shown in Figure 3. Obviously, the greatest extraction of alumina is observed at $300{ }^{\circ} \mathrm{C}$, since the decomposition degree of silicon-containing minerals is low at this temperature, and boehmite and even diaspore almost completely convert into sodium aluminate.
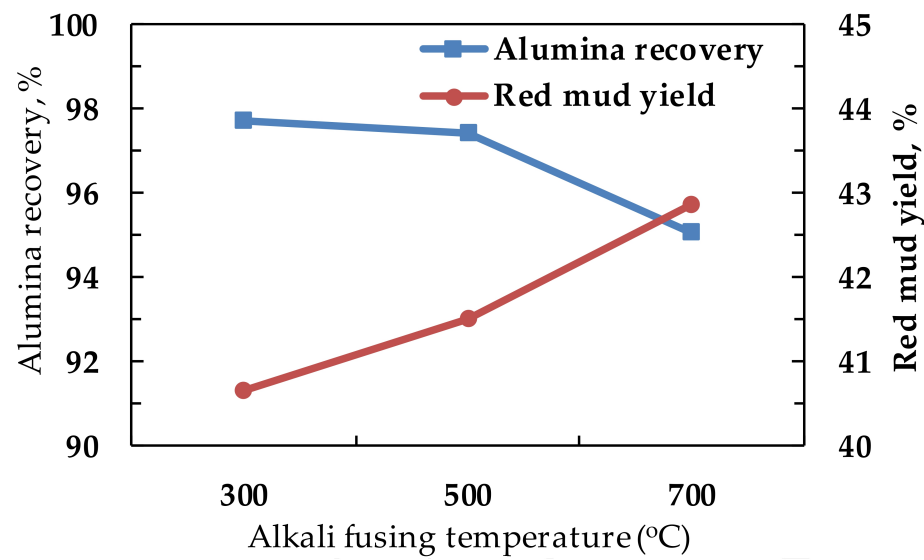

Figure 3. The influence of fusion temperature on alumina extraction and the yield of red mud.

As the temperature rises further, quartz and chamosite begin to interact, which leads to the transfer of silicon to the solution as the sinter is leached in the form of sodium silicate, which in turn interacts with sodium aluminate to form the desilication product by Equation (7). The formation of the desilication product, while binding alumina, also negatively affects the red mud output.

$$
6 \mathrm{NaAl}(\mathrm{OH})_{4}+6 \mathrm{Na}_{2} \mathrm{SiO}_{3}+\mathrm{Na}_{2} \mathrm{X}=\mathrm{Na}_{6}\left(\mathrm{Al}_{6} \mathrm{Si}_{6} \mathrm{O}_{24}\right) \times \mathrm{Na}_{2} \mathrm{X} \times y \mathrm{H}_{2} \mathrm{O}+12 \mathrm{NaOH},
$$

where $X$ represents a variety of inorganic anions, most commonly sulphate, carbonate, chloride, sodium aluminate, and hydroxide. Thus, $300{ }^{\circ} \mathrm{C}$ is the best temperature among those studied in terms of increasing the alumina extraction and reducing the amount of mud formed. However, finding of the optimal conditions for bauxite fusion with caustic alkali requires additional research.

\subsection{Red Mud Characterization}

A total of five red muds were used in this study: the industrial muds obtained from th eBayer process and the sinter process, and three red muds obtained by fusing bauxite with caustic alkali at different temperatures. They were subjected to various physicochemical methods of analysis to determine the effect of the bauxite processing method on mud properties.

Table 2 presents the chemical compositions of these red muds. Obviously, the highest iron content was observed in the red mud obtained by alkali fusion at $300{ }^{\circ} \mathrm{C}$. Industrial red muds are the poorest in iron, containing a large amount of caustic alkali, aluminum, silicon, and calcium. It is worth noting the difference in the LOI values between the red muds obtained by alkali fusion at $300{ }^{\circ} \mathrm{C}$ and $500{ }^{\circ} \mathrm{C}$, which indicates a higher iron hydroxide content in the first red mud.

Figure 4 shows the XRD patterns of red muds. As can be seen, the industrial Bayer red mud contains hematite and sodium aluminosilicates as the main phase, which is caused by the lack of alkali reaction with iron compounds during autoclave leaching and desilication product precipitation (Equation (7)). Industrial sintering mud is poorly crystallized, but it contains a hydrated form of iron-limonite-as the main phase [61], which is formed as sodium ferrite is leached with water (Equation (8)): 


$$
\mathrm{NaFeO}_{2}+\mathrm{H}_{2} \mathrm{O}=\mathrm{FeOOH}+\mathrm{NaOH},
$$

Table 2. The chemical compositions of red muds, wt. \%.

\begin{tabular}{cccccccc}
\hline Red Mud & $\mathbf{N a}_{\mathbf{2}} \mathbf{O}$ & $\mathbf{A l}_{\mathbf{2}} \mathbf{O}_{\mathbf{3}}$ & $\mathbf{F e}_{\mathbf{2}} \mathbf{O}_{\mathbf{3}}$ & $\mathbf{S i O}_{\mathbf{2}}$ & $\mathbf{T i O}_{\mathbf{2}}$ & $\mathbf{C a O}$ & $\mathbf{L O I}$ \\
\hline Bayer process & 5.16 & 13.3 & 53.21 & 12.04 & 5.48 & 5.98 & 4.20 \\
Sinter process & 7.82 & 12.8 & 40.10 & 12.05 & 4.10 & 8.40 & 12.54 \\
Alkali fusion $300{ }^{\circ} \mathrm{C}$ & 1.53 & 3.87 & 67.80 & 4.93 & 6.88 & 1.50 & 10.84 \\
Alkali fusion $500{ }^{\circ} \mathrm{C}$ & 2.60 & 7.02 & 66.83 & 5.30 & 6.78 & 1.48 & 7.10 \\
Alkali fusion $700{ }^{\circ} \mathrm{C}$ & 2.50 & 7.84 & 65.34 & 5.18 & 6.63 & 1.40 & 8.20 \\
\hline
\end{tabular}

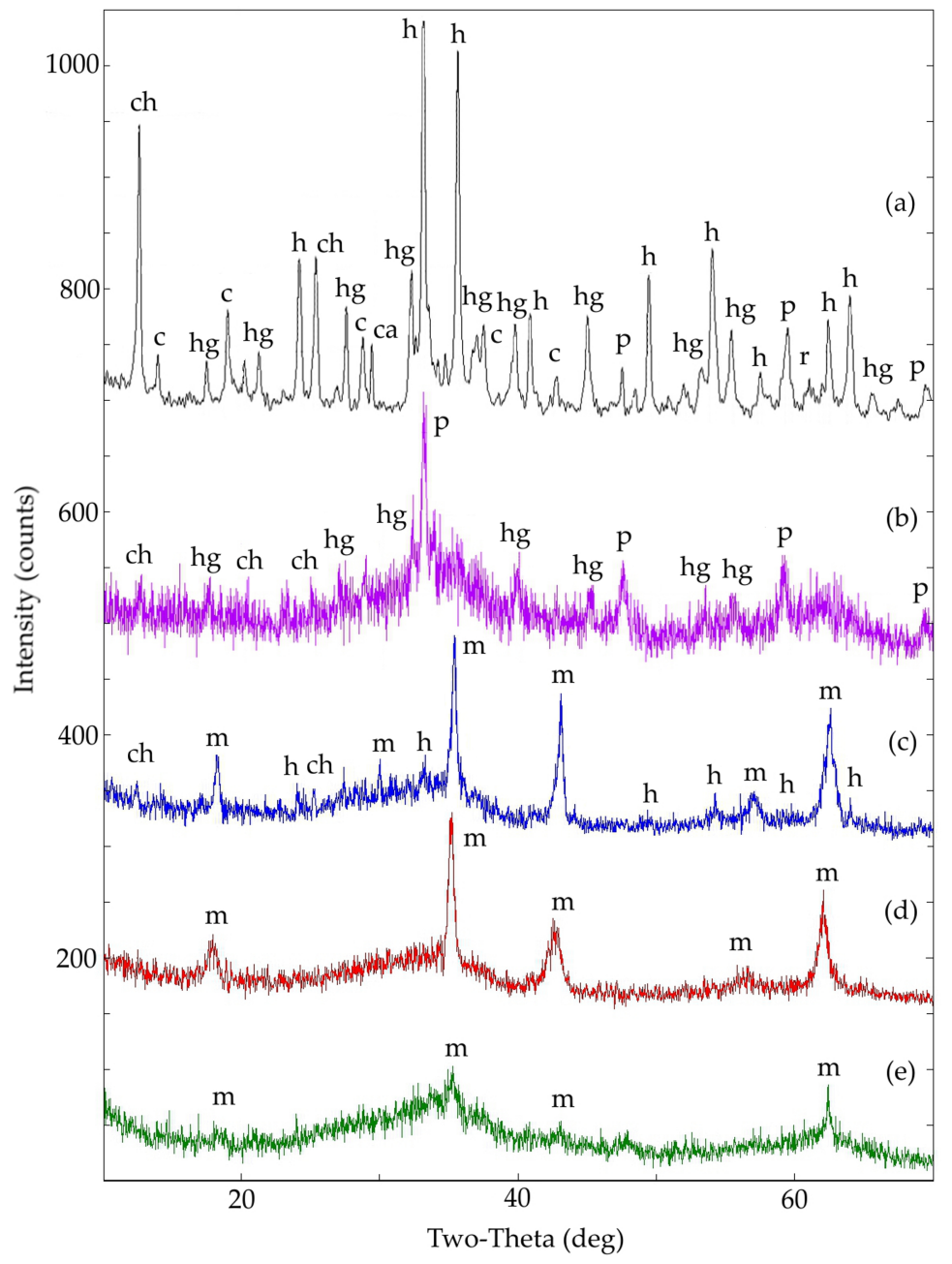

Figure 4. XRD pattern of red muds: (a) industrial Bayer red mud; (b) industrial sintering red mud; (c) red mud obtained by alkali fusion at $300{ }^{\circ} \mathrm{C}$; (d) red mud obtained by alkali fusion at $500{ }^{\circ} \mathrm{C}$; (e) red mud obtained by alkali fusion at $700^{\circ} \mathrm{C}$. The letters stand for: ch, chamosite; c, cancrinite (desilication product); hg, hydrogarnet; $h$, hematite; ca, calcite; $p$, perovskite; $r$, rutile; $m$, maghemite.

The red mud obtained by alkali fusion contains maghemite as the main phase. The mechanism of formation of maghemite in this case is not completely clear, but in our opinion it is associated with the transformation of lepidocrocyte and ferrihydrite in aqueous solutions, analogous to the process described in References [67]. At the initial moment, sodium ferrite is hydrolyzed in an aqueous solution to form iron hydroxide, which then at elevated temperatures is transformed into maghemite in the presence of certain ligands, which inhibit their transition to hematite. The latter phenomenon requires further study. 
The peaks were broader at $500{ }^{\circ} \mathrm{C}$ as compared to $300{ }^{\circ} \mathrm{C}$, due to the smaller degree of crystallinity, whereas the morphology of these two red muds was almost identical (Figure 5). At the same time, the red mud obtained at $700{ }^{\circ} \mathrm{C}$ consisted of much larger particles, and the industrial red mud had particles of irregular size, as it contained a large amount of impurities (see Table 2).

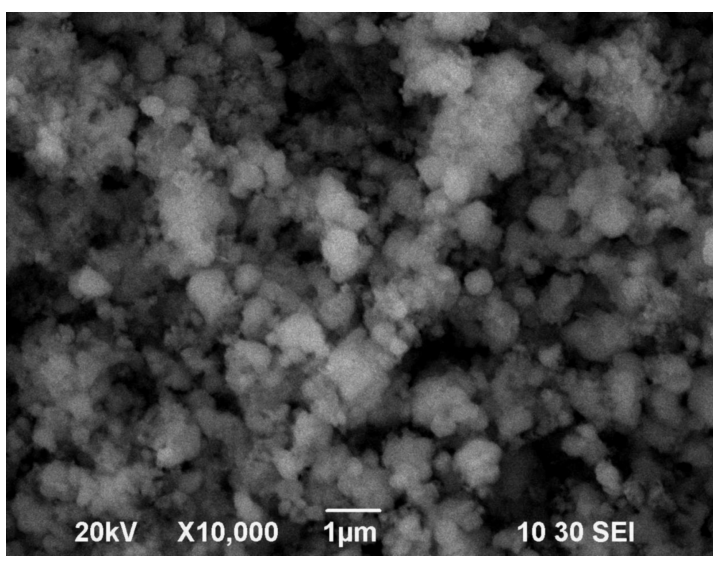

(a)

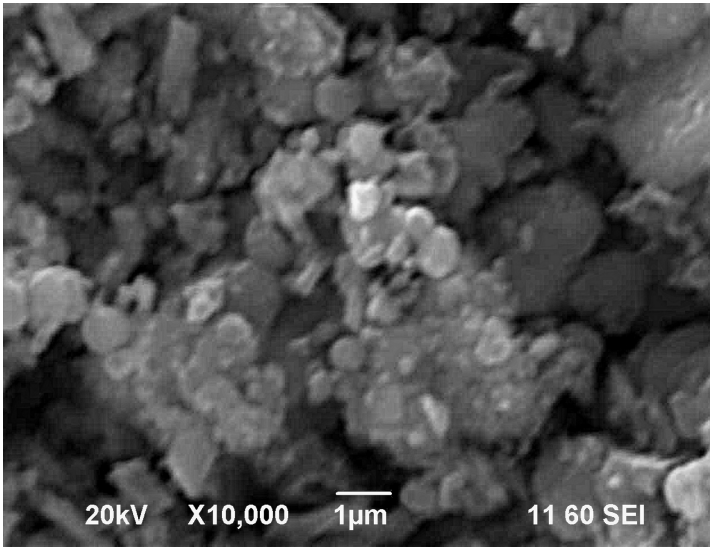

(c)

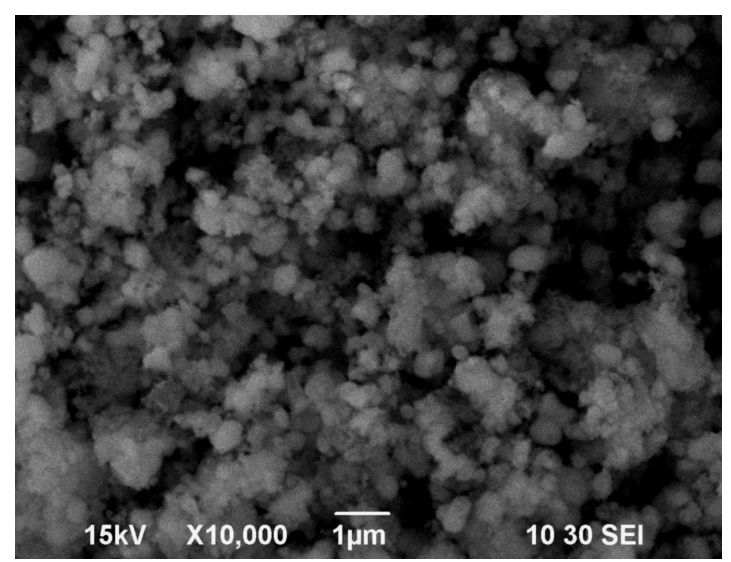

(b)

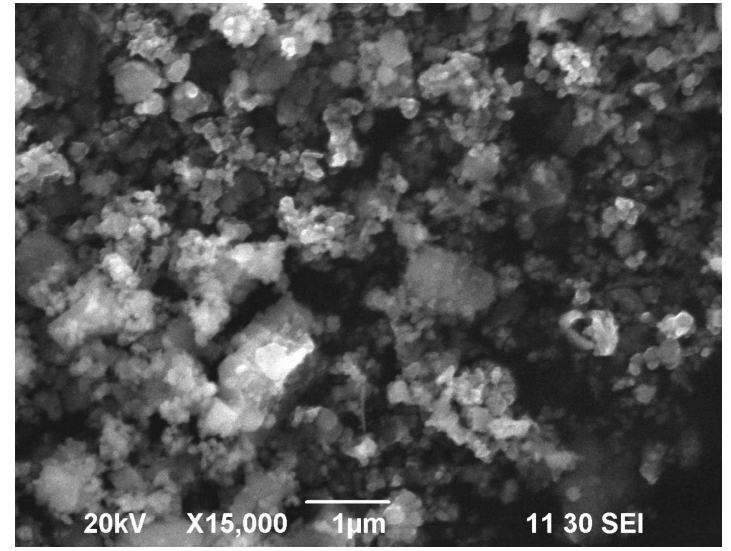

(d)

Figure 5. Microphotographs of red muds: (a) red mud obtained by alkali fusion at $300{ }^{\circ} \mathrm{C}$; (b) red mud obtained by alkali fusion at $500{ }^{\circ} \mathrm{C}$; (c) red mud obtained by alkali fusion at $500{ }^{\circ} \mathrm{C}$; (d) industrial Bayer red mud.

The XRD patterns of maghemite and magnetite were close. However, the amount of ferrous iron in the red muds was very low and was related to unleached chamosite, the peaks of which could be found in the red mud obtained at $300^{\circ} \mathrm{C}$.

At $300{ }^{\circ} \mathrm{C}$, small peaks of hematite were also observed, which disappear at $500{ }^{\circ} \mathrm{C}$. At $700{ }^{\circ} \mathrm{C}$, the red mud became almost amorphous; however, maghemite was still detectable by XRD.

Table 3 presents the results of the study of the physical properties of red muds: specific surface area, pore volume, zero charge point, and VSM magnetization. Red muds obtained by alkali fusion at $300{ }^{\circ} \mathrm{C}$ and $500{ }^{\circ} \mathrm{C}$ had the largest surface areas. They also showed the greatest magnetizations. The zero charge points were comparable with the literature data for maghemite-based adsorbents [59], according to which it varied from 5 to $8 \mathrm{pH}$.

Red mud obtained by fusion at $700{ }^{\circ} \mathrm{C}$ is practically nonmagnetic, so the maghemite content is very low. This appears to be due to the structural changes of ferrite at this temperature, which were found on the XRD pattern (Figure 2). Industrial red muds are also practically non-magnetic and thus were not studied for magnetization level. 
Table 3. The chemical composition of red muds.

\begin{tabular}{|c|c|c|c|c|}
\hline Red Mud & $\begin{array}{c}\text { BET Specific Surface } \\
\text { Area }\left(\mathrm{m}^{2} / \mathrm{g}\right)\end{array}$ & $\begin{array}{l}\text { Pore Volume } \\
\times 10^{-3}\left(\mathrm{sm}^{3} / \mathrm{g}\right) \\
\end{array}$ & $\mathrm{pH}_{\mathrm{pzc}}$ & $\begin{array}{l}\text { VSM Magnetization } \\
\text { at } 10 \mathrm{kOe}(\mathrm{emu} / \mathrm{g})\end{array}$ \\
\hline Bayer process & 22.51 & 38.7 & -1 & -2 \\
\hline Sinter process & 7.15 & 11.4 & -1 & -2 \\
\hline Alkali fusion at $300{ }^{\circ} \mathrm{C}$ & 54.97 & 76.4 & 7.5 & 19 \\
\hline Alkali fusion at $500{ }^{\circ} \mathrm{C}$ & 51.77 & 70.6 & 7.4 & 20 \\
\hline Alkali fusion at $700{ }^{\circ} \mathrm{C}$ & 6.40 & 13.3 & -1 & -2 \\
\hline
\end{tabular}

${ }^{1}$ These parameters were not studied. ${ }^{2}$ These red muds were nonmagnetic. BET, the Brunauer-Emmett-Teller method. VSM, vibrating sample magnetometer.

Figure 6 shows the magnetization levels of red muds obtained by alkali fusion at 300 and $500{ }^{\circ} \mathrm{C}$. It can be seen that both samples reach a maximum magnetization of 19-20 emu/g with a magnetic field of $10 \mathrm{kOe}$. These values are lower than those of maghemite according to the literature [55]. However, they are comparable with the value determined for nanoparticles of maghemite obtained by mechanical activation.

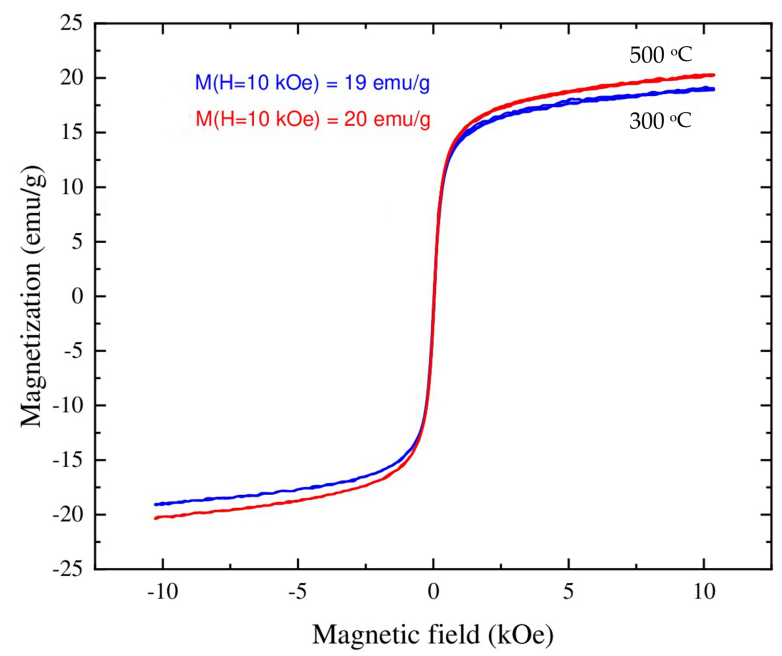

Figure 6. Magnetization curves for red muds obtained by fusion at 300 and $500{ }^{\circ} \mathrm{C}$.

\subsection{As (V) Batch Adsorption Experiments}

\subsubsection{Arsenic Adsorption Effectiveness by Various Types of Red Mud}

Figure 7 shows the results of experiments with arsenic adsorption from a solution with an initial arsenic concentration of $156 \mathrm{mg} / \mathrm{L}$ for $48 \mathrm{~h}$ by various types of red mud.

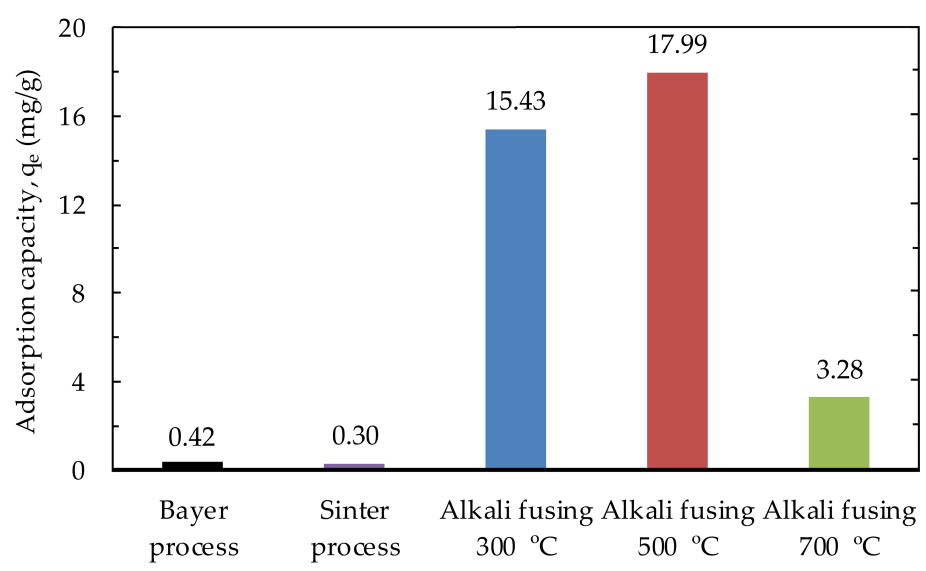

Figure 7. As (V) adsorption capacity of different red muds. 
It is obvious that the uptake capacities of red muds obtained in different ways vary significantly. Industrial red muds have the smallest uptake capacity (from 300 to $420 \mu \mathrm{g} / \mathrm{g}$ ) (which is in good agreement with the literature data [45] for industrial red muds and with the data in Table 3) since they have the smallest surface area and differ in phase composition. For example, industrial red muds contain a large amount of desilication products and calcium compounds that dissolve easily, even in dilute acid solutions, which ultimately can lead to a strong $\mathrm{pH}$ increase up to a point of zero charge and higher. This, in turn, results in a decrease in the arsenic adsorption effectiveness.

Apart from that, the data in Figure 7 show that the red mud obtained by fusion at $700{ }^{\circ} \mathrm{C}$ also has a much smaller capacity than those obtained at lower temperatures. Apparently, this is also due to the difference in specific surface area and the phase composition, since red mud at a fusion temperature of $700{ }^{\circ} \mathrm{C}$ contains few maghemite nanoparticles.

Further experiments looked at the adsorption characteristics of only two types of red mud with the highest content of maghemite nanoparticles that can be separated from the solution by an external magnetic field. To this end, studies of adsorption kinetics were carried out to determine the duration of the experiments that is sufficient to achieve pseudo-equilibrium. The results of the experiments are shown in Figure 8. We can see that a 24-h contact of the solution with the red mud is sufficient to achieve saturation.

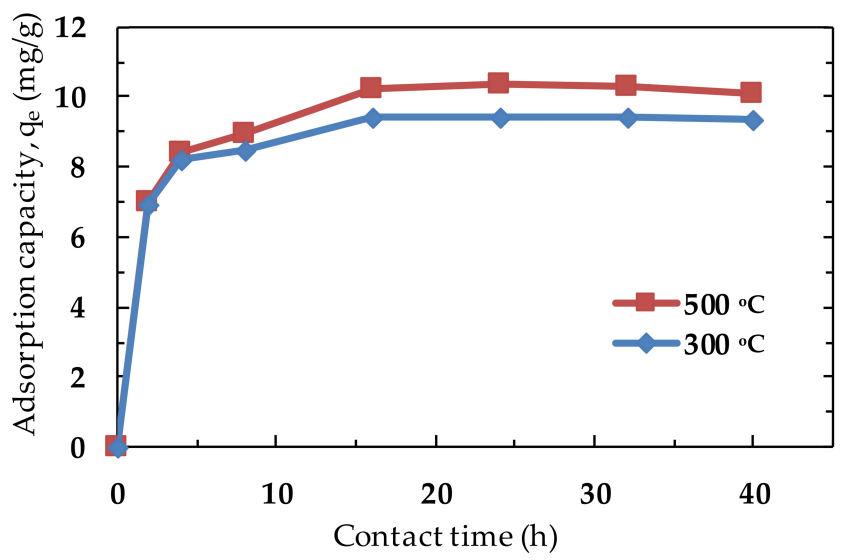

Figure 8. Kinetics of arsenic adsorption by muds obtained by alkali fusion at 300 and $500{ }^{\circ} \mathrm{C}$.

\subsubsection{The Effect of the Initial $\mathrm{pH}$ of the Solution on the Arsenic Uptake Capacity of Red Muds}

The $\mathrm{pH}$ value of the solution greatly affects the capacity of iron oxide sorbents, since at a $\mathrm{pH}$ below the zero charge point, the surface of the sorbent acquires positive charge and attracts oppositely charged arsenic oxyanions. When the solution $\mathrm{pH}$ rises above the zero charge point, the sorbent surface charge becomes negative, and the opposite forces start to act. Additionally, at a $\mathrm{pH}$ above 7-9, more stable arsenic anions [68] are formed in the solution. For red muds obtained by alkali fusion at 300 and $500{ }^{\circ} \mathrm{C}$, the zero charge points are approximately equal at 7.4 and 7.5 , respectively, which agrees well with the experimental data shown in Figure 9.

As can be seen, the uptake capacity of the red mud obtained at $500{ }^{\circ} \mathrm{C}$ at all $\mathrm{pH}$ values slightly exceeded the capacity of the red mud obtained at $300{ }^{\circ} \mathrm{C}$; at a $\mathrm{pH}$ higher than 10 , the capacities began to level off, apparently due to the onset of arsenic desorption. The largest uptake capacity was achieved at a $\mathrm{pH}$ of 2.3. After that, there was a sharp decrease in capacity down to $\mathrm{pH}=4$; then the capacity remained virtually unchanged until the zero charge point, after which the capacity started to decrease again. 


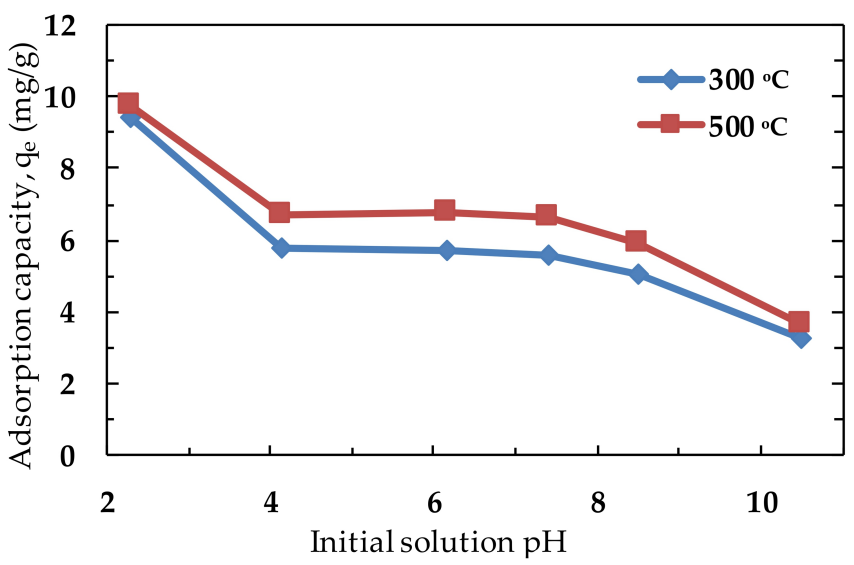

Figure 9. The effect of the initial $\mathrm{pH}$ of the solution on arsenic adsorption with red muds obtained by alkali fusion at 300 and $500{ }^{\circ} \mathrm{C}$.

\subsubsection{Arsenic Adsorption Isotherms}

The adsorption isotherms were obtained with an initial solution $\mathrm{pH}$ of 2.3 and different concentrations of arsenic for two types of red mud. The results of the experiments were graphically compared to the equations of the isotherms of Langmuir and Freundlich (Figure 10). The data are presented in Table 4.

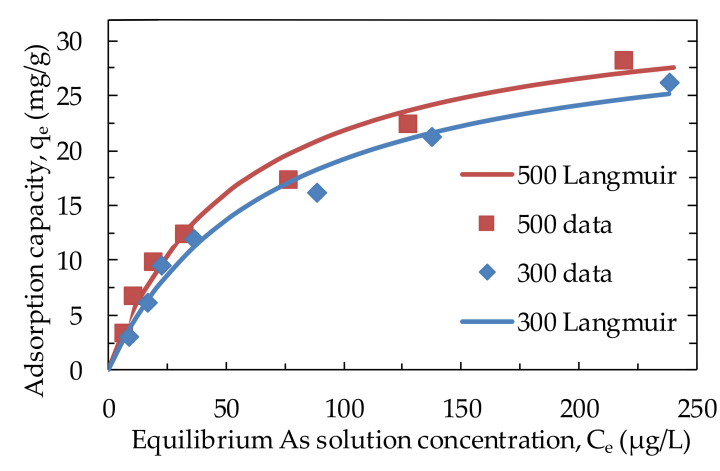

(a)

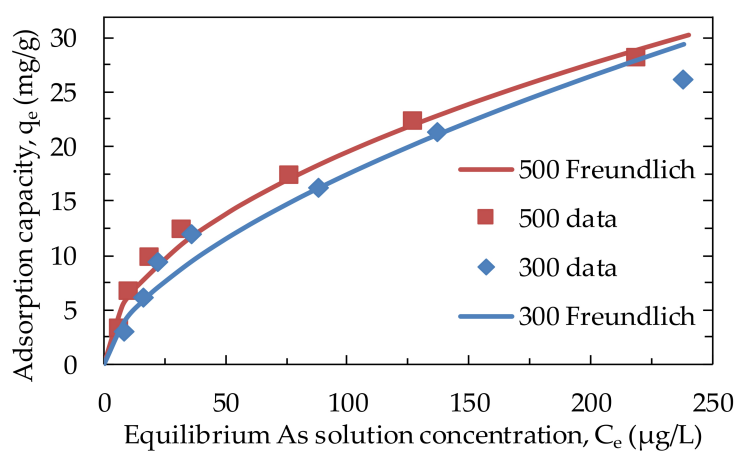

(b)

Figure 10. Arsenic adsorption isotherms with red mud obtained by alkali fusion at 300 and $500{ }^{\circ} \mathrm{C}$ : (a) Langmuir isotherm equation, (b) Freundlich isotherm equation.

Table 4. Adsorption isotherms and the parameters most suitable to the data obtained.

\begin{tabular}{ccccccc}
\hline \multirow{2}{*}{ Red Mud } & \multicolumn{3}{c}{ Langmuir } & \multicolumn{3}{c}{ Freundlich } \\
\cline { 2 - 7 } & $\mathbf{K}_{\mathbf{L}} \mathbf{( L / m g )}$ & $\mathbf{q}_{\mathbf{m a x}}(\mathbf{m g} / \mathbf{g})$ & $\mathbf{R}^{\mathbf{2}}$ & $\mathbf{K}_{\mathbf{f}} \mathbf{(}(\mathbf{m g} / \mathbf{g})(\mathbf{L} / \mathbf{m g})^{\mathbf{1} / \mathbf{n})}$ & $\mathbf{n}$ & $\mathbf{R}^{\mathbf{2}}$ \\
\hline Alkali fusion $300^{\circ} \mathrm{C}$ & 0.0145 & 32.5 & 0.98 & 1.10 & 1.67 & 0.96 \\
Alkali fusion $500^{\circ} \mathrm{C}$ & 0.0180 & 34.0 & 0.95 & 1.95 & 2.00 & 0.97 \\
\hline
\end{tabular}

The obtained results suggest that the experimental data at $500{ }^{\circ} \mathrm{C}$ are in better agreement with the Freundlich isotherm equation, which point toward the preference of multilayer sorption. The experimental data at $300{ }^{\circ} \mathrm{C}$ are in good agreement with the Langmuir and Freundlich isotherm equations. A feature of the Langmuir equation is the ability to determine the maximum capacity of the sorbent and the values $\mathrm{R}_{\mathrm{L}}=\left(1+\mathrm{K}_{\mathrm{L}} \times \mathrm{C}_{0}\right)-1$, where $\mathrm{C}_{0}$ is the initial concentration of the substance in the solution. So, when the initial concentration of $C_{0}=250 \mathrm{mg} / \mathrm{L}$, we obtain a value of $\mathrm{R}_{\mathrm{L}}$ equal to 0.18 , which suggests that adsorption has an advantage [53].

The maximum capacity values obtained by the Langmuir equation for red muds obtained by bauxite fusion at 300 and $500{ }^{\circ} \mathrm{C}$ are 32.5 and $34.0 \mathrm{mg} / \mathrm{g}$, respectively, which is in good agreement 
with the literature data on As (V) adsorption by maghemite nanoparticles [59]. It is worth noting that the specific surface area is larger for the sample obtained at $300{ }^{\circ} \mathrm{C}$, but the transformation degree of hematite to maghemite is larger for the sample obtained at $500{ }^{\circ} \mathrm{C}$, which indicates the predominant influence of the maghemite content in the sample. The same conclusion can be made for the adsorption capacity of industrial red muds, which have no maghemite nanoparticles in the phase composition. As a result, their adsorption capacity is significantly lower than that of the samples obtained by alkali fusion. Still, industrial red muds contain large amounts of desilication products and calcium compounds.

\section{Conclusions}

The results of this study can be summarized as follows:

1. Fusing bauxite with alkali at $300-500{ }^{\circ} \mathrm{C}$ is an efficient method of converting iron-containing minerals into maghemite nanoparticles.

2. Red mud obtained in this way can be effectively used to remove arsenic from solutions, since its capacity is significantly higher than that of industrial samples (17.99 versus $0.42 \mathrm{mg} / \mathrm{g}$ under the same conditions).

3. The efficiency of the adsorption of arsenic by maghemite-containing red mud depends on the original $\mathrm{pH}$, the contact duration, and the initial concentration of As in the solution.

4. The experimental data correlate well with Langmuir and Freundlich adsorption equations.

5. The maximum As (V) uptake capacities of the adsorbents obtained at 300 and $500{ }^{\circ} \mathrm{C}$ at initial $\mathrm{pH}=2.3$ were $32.5 \mathrm{mg} / \mathrm{g}$ and $34.0 \mathrm{mg} / \mathrm{g}$, respectively.

6. The differences in uptake capacity appear to be related to the content of maghemite nanoparticles in the samples.

Author Contributions: Conceptualization, I.V.L. and A.A.S.; methodology, K.A.K.; validation, L.I.C., I.V.L.; formal analysis, A.A.S., D.A.R.; investigation, A.A.S., K.A.K.; resources, L.I.C., K.A.K. data curation, D.A.R.; writing-original draft preparation, A.A.S.; writing—review and editing, I.V.L., D.A.R.; visualization, A.A.S., L.I.C.; supervision, A.A.S.; project administration, A.A.S.; funding acquisition, D.A.R.

Funding: The study of the alkali fusion-leaching of bauxite was funded by State Assignment, grant number 10.7347.2017/8.9. The research of arsenic removal was funded by the Russian Science Foundation, grant number 18-19-00186.

Acknowledgments: RUSAL-Kamensk-Uralsky and Ural Mining and Metallurgical Company are acknowledged for providing materials. Technicians at Ural Branch of Russian Academy of Sciences are acknowledged for their assistance with XRD, XRF, SEM, VSM, BET, and ICP-MS analysis.

Conflicts of Interest: The authors declare no conflict of interest. The funders had no role in the design of the study; in the collection, analyses, or interpretation of data; in the writing of the manuscript, or in the decision to publish the results.

\section{References}

1. Gibson, B.; Wonyen, D.G.; Chehreh Chelgani, S. A review of pretreatment of diasporic bauxite ores by flotation separation. Miner. Eng. 2017, 114, 64-73. [CrossRef]

2. Hind, A.; Bhargava, S.; Grocott, S. The surface chemistry of Bayer process solids: A review. Colloids Surf. A 1999, 146, 359-374. [CrossRef]

3. Authier-Martin, M.; Forté, G.; Ostap, S.; See, J. The mineralogy of bauxite for producing smelter-grade alumina. JOM 2001, 53, 36-40. [CrossRef]

4. Kaußen, F.; Friedrich, B. Methods for Alkaline Recovery of Aluminum from Bauxite Residue. J. Sustain. Metall. 2016, 2, 353-364. [CrossRef]

5. Paramguru, R.K.; Rath, P.C.; Misra, V.N. Trends in red mud utilization: A review. Miner. Process. Extr. Metall. Rev. 2005. [CrossRef] 
6. Li, X.B.; Xiao, W.; Liu, W.; Liu, G.H.; Peng, Z.H.; Zhou, Q.S.; Qi, T.G. Recovery of alumina and ferric oxide from Bayer red mud rich in iron by reduction sintering. Trans. Nonferr. Metal. Soc. 2009, 19, 1342-1347. [CrossRef]

7. Ruyters, S.; Mertens, J.; Vassilieva, E.; Dehandschutter, B.; Poffijn, A.; Smolders, E. The Red Mud Accident in Ajka (Hungary): Plant Toxicity and Trace Metal Bioavailability in Red Mud Contaminated Soil. Environ. Sci. Technol. 2011, 45, 1616-1622. [CrossRef]

8. Winkler, D.; Bidló, A.; Bolodár-Varga, B.; Erdő, A.; Horváth, A. Long-term ecological effects of the red mud disaster in Hungary: Regeneration of red mud flooded areas in a contaminated industrial region. Sci. Tota Environ. 2018, 644, 1292-1303. [CrossRef]

9. Courtney, R.G.; Timpson, J.P. Nutrient status of vegetation grown in alkaline bauxite processing residue amended with gypsum and thermally dried sewage sludge-A two year field study. Plant Soil 2004, 266, 187-194. [CrossRef]

10. Wehr, J.B.; Fulton, I.; Menzies, N.W. Revegetation Strategies for Bauxite Refinery Residue: A Case Study of Alcan Gove in Northern Territory, Australia. Environ. Manag. 2006, 37, 297-306. [CrossRef]

11. Aughinish Alumina Ltd. Annual Environmental Report 2008. Available online: http://www.epa.ie/ licences/lic_eDMS/090151b2802a9459.pdf (accessed on 12 February 2018).

12. Power, G.; Gräfe, M.; Klauber, C. Bauxite residue issues: I. Current management, disposal and storage practices. Hydrometallurgy 2011, 108, 33-45. [CrossRef]

13. Zhang, T.; Wang, Y.; Lu, G.; Liu, Y.; Zhang, W.; Zhao, Q. Comprehensive Utilization of Red Mud: Current Research Status and a Possible Way Forward for Non-hazardous Treatment. In Light Metals 2018, Proceedings of the TMS 2018, Phoenix, AZ, USA, 11-15 March 2018; The Minerals, Metals \& Materials Series; Martin, O., Ed.; Springer: Cham, Switzerland, 2018; pp. 135-141.

14. Tsakiridis, P.E.; Agatzini-Leonardou, S.; Oustadakis, P. Red mud addition in the raw meal for the production of Portland cement clinker. J. Hazard. Mater. 2004, 116, 103-110. [CrossRef] [PubMed]

15. Liu, W.; Yang, J.; Xiao, B. Review on treatment and utilization of bauxite residues in China. Int. J. Miner. Process. 2009, 93, 220-231. [CrossRef]

16. Liu, W.; Yang, J.; Xiao, B. Application of Bayer red mud for iron recovery and building material production from alumosilicate residues. J. Hazard. Mater. 2009, 161, 474-478. [CrossRef] [PubMed]

17. Yang, H.; Chen, C.; Pan, L.; Lu, H.; Sun, H.; Hu, X. Preparation of double-layer glass-ceramic/ceramic tile from bauxite tailings and red mud. J. Eur. Ceram. Soc. 2009, 29, 1887-1894. [CrossRef]

18. Borra, C.R.; Pontikes, Y.; Binnemans, K.; Van Gerven, T. Leaching of rare earths from bauxite residue (red mud). Miner. Eng. 2015, 76, 20-27. [CrossRef]

19. Liu, Z.; Li, H. Metallurgical process for valuable elements recovery from red mud-A review. Hydrometallurgy 2015, 155, 29-43. [CrossRef]

20. Klauber, C.; Gräfe, M.; Power, G. Bauxite residue issues: II. options for residue utilization. Hydrometallurgy 2011, 108, 11-32. [CrossRef]

21. Fan, H.L.; Li, C.H.; Xie, K.C. Testing of iron oxide sorbent for high-temperature coal gas desulfurization. Energy Sources 2005, 27, 245-250. [CrossRef]

22. Santona, L.; Castaldi, P.; Melis, P. Evaluation of the interaction mechanisms between red muds and heavy metals. J. Hazard. Mater. 2006, 136, 324-329. [CrossRef] [PubMed]

23. Agrawal, A.; Sahu, K.K.; Pandey, B.D. A comparative adsorption study of copper on various industrial solid wastes. AICHE J. 2004, 50, 2430-2438. [CrossRef]

24. Ahmed, M.D.J.K.; Ahmaruzzaman, M. A review on potential usage of industrial waste materials for binding heavy metal ions from aqueous solutions. J. Water Process Eng. 2016, 10, 39-47. [CrossRef]

25. Altundogan, H.S.; Altundogan, S.; Tümen, F.; Bildik, M. Arsenic removal from aqueous solutions by adsorption on red mud. Waste Manag. 2000, 20, 761-767. [CrossRef]

26. Wang, S.; Mulligan, C.N. Speciation and surface structure of inorganic arsenic in solid phases: A review. Environ. Int. 2008, 34, 867-879. [CrossRef] [PubMed]

27. Cullen, W.R.; Reimer, K.J. Arsenic Speciation in the Environment. Chem. Rev. 1989, 89, 713-764. [CrossRef]

28. Ahmed, K.M.; Bhattacharya, P.; Hasan, M.A.; Akhter, A.H.; Alam, S.M.M.; Bhuyian, M.A.H.; Imam, M.B.; Khan, A.A.; Sracek, O. Arsenic enrichment in groundwater of the alluvial aquifers in Bangladesh: An overview. Appl. Geochem. 2004, 19, 181-200. [CrossRef] 
29. Brammer, H.; Ravenscroft, P. Arsenic in groundwater: A threat to sustainable agriculture in South and South-east Asia. Environ. Int. 2009, 35, 647-654. [CrossRef] [PubMed]

30. Zheng, Y.; Stute, M.; Van Geen, A.; Gavrieli, I.; Dhar, R.; Simpson, H.J.; Schlosser, P.; Ahmed, K.M. Redox control of arsenic mobilization in Bangladesh groundwater. Appl. Geochem. 2004, 19, 201-214. [CrossRef]

31. Karimov, K.A.; Naboichenko, S.S. Sulfuric acid leaching of high-arsenic dust from copper smelting. Metallurgist 2016, 60, 456-459. [CrossRef]

32. Piret, N.L. Removal and safe disposal of arsenic in copper processing. JOM 1999, 51, 16-17. [CrossRef]

33. McClintock, T.R.; Chen, Y.; Bundschuh, J.; Oliver, J.T.; Navoni, J.; Olmos, V.; Lepori, E.V.; Ahsan, H.; Parvez, F. Arsenic exposure in Latin America: Biomarkers, risk assessments and related health effects. Sci. Total Environ. 2012, 429, 76-91. [CrossRef] [PubMed]

34. Chen, B.-C.; Chou, W.-C.; Chen, W.-Y.; Liao, C.-M. Assessing the cancer risk associated with arsenic-contaminated seafood. J. Hazard. Mater. 2010, 181, 161-169. [CrossRef] [PubMed]

35. Smith, A.H.; Smith, M.M.H. Arsenic drinking water regulations in developing countries with extensive exposure. Toxicology 2004, 198, 39-44. [CrossRef] [PubMed]

36. Smith, A.H.; Lopipero, P.A.; Bates, M.N.; Steinmaus, C.M. Arsenic epidemiology and drinking water standards. Science 2002, 296, 2145-2146. [CrossRef] [PubMed]

37. Bissen, M.; Frimmel, F.H. Arsenic-A review. Part II: Oxidation of arsenic and its removal in water treatment. Acta Hydrochim. Hydrobiol. 2003, 31, 97-107. [CrossRef]

38. Kumar, P.R.; Chaudhari, S.; Khilar, K.C.; Mahajan, S.P. Removal of arsenic from water by electrocoagulation. Chemosphere 2004, 55, 1245-1252. [CrossRef] [PubMed]

39. De Klerk, R.J.; Jia, Y.; Daenzer, R.; Gomez, M.A.; Demopoulos, G.P. Continuous circuit coprecipitation of arsenic(V) with ferric iron by lime neutralization: Process parameter effects on arsenic removal and precipitate quality. Hydrometallurgy 2012, 111, 65-72. [CrossRef]

40. Abejón, A.; Garea, A.; Irabien, A. Arsenic removal from drinking water by reverse osmosis: Minimization of costs and energy consumption. Sep. Purif. Technol. 2015, 144, 46-53. [CrossRef]

41. Yuan, S.; Xie, S.; Zhao, K.; Gan, Y.; Wang, Y. Field tests of in-well electrolysis removal of arsenic from high phosphate and iron groundwater. Sci. Total Environ. 2018, 644, 1630-1640. [CrossRef]

42. Kim, J.; Benjamin, M.M. Modeling a novel ion exchange process for arsenic and nitrate removal. Water Res. 2004, 38, 2053-2062. [CrossRef]

43. Mohan, D.; Pittman, C.U., Jr. Arsenic removal from water/wastewater using adsorbents-A critical review. J. Hazard. Mater. 2007. [CrossRef] [PubMed]

44. Siddiqui, S.I.; Chaudhry, S.A. Iron oxide and its modified forms as an adsorbent for arsenic removal: A comprehensive recent advancement. Process. Saf. Environ. 2017, 111, 592-626. [CrossRef]

45. Bhatnagar, A.; Vilar, V.J.P.; Botelho, C.M.S.; Boaventura, R.A.R. A review of the use of red mud as adsorbent for the removal of toxic pollutants from water and wastewater. Environ. Technol. 2011, 32, 231-249. [CrossRef] [PubMed]

46. Sahu, R.C.; Patel, R.; Ray, B.C. Utilization of activated $\mathrm{CO}_{2}$-neutralized red mud for removal of arsenate from aqueous solutions. J. Hazard. Mater. 2010, 179, 1007-1013. [CrossRef] [PubMed]

47. Venkatesan, G.; Narayanan, S.L. Synthesis of $\mathrm{Fe}_{2} \mathrm{O}_{3}$-coated and HCl-treated bauxite ore waste for the adsorption of arsenic (III) from aqueous solution: Isotherm and kinetic models. Chem. Eng. Commun. 2018, 205, 34-46. [CrossRef]

48. Zhang, S.; Liu, C.; Luan, Z.; Peng, X.; Ren, H.; Wang, J. Arsenate removal from aqueous solutions using modified red mud. J. Hazard. Mater. 2008, 152, 486-492. [CrossRef]

49. Genç-Fuhrman, H.; Tjell, J.C.; McConchie, D. Adsorption of Arsenic from Water Using Activated Neutralized Red Mud. Environ. Sci. Technol. 2004, 38, 2428-2434. [CrossRef]

50. Altundogan, H.S.; Altundogan, S.; Tümen, F.; Bildik, M. Arsenic adsorption from aqueous solutions by activated red mud. Waste Manag. 2002, 22, 357-363. [CrossRef]

51. Genç-Fuhrman, H.; Tjell, J.C.; McConchie, D. Increasing the arsenate adsorption capacity of neutralized red mud (Bauxsol). J. Colloid Interface Sci. 2004, 271, 313-320. [CrossRef]

52. López-García, M.; Martínez-Cabanas, M.; Vilariño, T.; Lodeiro, P.; Rodríguez-Barro, P.; Herrero, R.; Barriada, J.L. New polymeric/inorganic hybrid sorbents based on red mud and nanosized magnetite for large scale applications in As(V) removal. Chem. Eng. J. 2017, 311, 117-125. [CrossRef] 
53. Wu, C.; Huang, L.; Xue, S.-G.; Huang, Y.-Y.; Hartley, W.; Cui, M.-Q.; Wong, M.-H. Arsenic sorption by red mud-modified biochar produced from rice straw. Environ. Sci. Pollut. Res. 2017, 24, 18168-18178. [CrossRef] [PubMed]

54. Lopes, G.; Guilherme, L.R.G.; Costa, E.T.S.; Curi, N.; Penha, H.G.V. Increasing arsenic sorption on red mud by phosphogypsum addition. J. Hazard. Mater. 2013, 262, 1196-1203. [CrossRef] [PubMed]

55. Tuutijärvi, T.; Lub, J.; Sillanpää, M.; Chen, G. As(V) adsorption on maghemite nanoparticles. J. Hazard. Mater. 2009, 166, 1415-1420. [CrossRef] [PubMed]

56. Shokrollahi, H. A review of the magnetic properties, synthesis methods and applications of maghemite. J. Magn. Magn. Mater. 2017, 426, 74-81. [CrossRef]

57. Linley, S.; Leshuk, T.; Gu, F.X. Magnetically separable water treatment technologies and their role in future advanced water treatment: A patent review. Clean-Soil Air Water 2013, 41, 1152-1156. [CrossRef]

58. Simeonidis, K.; Mourdikoudis, S.; Kaprara, E.; Mitrakas, M.; Polavarapu, L. Inorganic engineered nanoparticles in drinking water treatment: A critical review. Environ. Sci. Water Res. 2016, 2, 43-70. [CrossRef]

59. Gómez-Pastora, J.; Bringas, E.; Ortiz, I. Recent progress and future challenges on the use of high performance magnetic nano-adsorbents in environmental applications. Chem. Eng. J. 2014, 256, 187-204. [CrossRef]

60. Akin, I.; Arslan, G.; Tor, A.; Ersoz, M.; Cengeloglu, Y. Arsenic(V) removal from underground water by magnetic nanoparticles synthesized from waste red mud. J. Hazard. Mater. 2012, 235-236, 62-68. [CrossRef] [PubMed]

61. Ma, S.-H.; Wen, Z.-G.; Chen, J.-N.; Zheng, S.-L. An environmentally friendly design for low-grade diasporic-bauxite processing. Miner. Eng. 2009, 22, 793-798. [CrossRef]

62. Le, T.; Ju, S.; Lu, L.; Peng, J.; Zhou, L.; Wang, S. A novel process and its mechanism for recovering alumina from diasporic bauxite. Hydrometallurgy 2017, 169, 124-134. [CrossRef]

63. Le, T.; Ju, S.; Koppala, S.; Peng, J.; Pan, B.; Zhang, L.; Wang, Q.; Li, X. Kinetics study of microwave enhanced reactions between diasporic bauxite and alkali solution. J. Alloy. Compd. 2018, 749, 652-663. [CrossRef]

64. Loginova, I.V.; Kyrchikov, A.V.; Lebedev, V.A.; Ordon, S.F. Investigation into the question of complex processing of bauxites of the srednetimanskoe deposit. Russ. J. Non-Ferrous Met. 2013, 54, 143-147. [CrossRef]

65. Loginova, I.V.; Shoppert, A.A.; Chaikin, L.I. Extraction of Rare-Earth Metals during the Systematic Processing of Diaspore-Boehmite Bauxites. Metallurgist 2016, 60, 198-203. [CrossRef]

66. Hristovski, K.D.; Markovski, J. Engineering metal (hydr)oxide sorbents for removal of arsenate and similar weak-acid oxyanion contaminants: A critical review with emphasis on factors governing sorption processes. Sci. Total Environ. 2017, 598, 258-271. [CrossRef] [PubMed]

67. Barrn, V.; Torrent, J. Evidence for a simple pathway to maghemite in Earth and Mars soils. Geochim. Cosmochim. Acta 2002, 66, 2801-2806. [CrossRef]

68. Streat, M.; Hellgardt, K.; Newton, N.L.R. Hydrous ferric oxide as an adsorbent in water treatment, Part 2. Adsorption studies. Process Saf. Environ. Prot. 2008, 86, 11-20. [CrossRef] 